\title{
Tenured Teachers \& Technology Integration In The Classroom
}

\author{
Jerad Cox, Boyle Street Education Centre, Edmonton, Alberta, Canada
}

\begin{abstract}
This article explores teachers' technology integration in the classroom through 2 means: 1) what researchers are saying about emerging trends and best practices as well as, 2) the author's research assignment regarding the technology integration experiences of longer tenured teachers. More tenured teachers are different than their younger colleague in that they did not receive the same quantity of preservice technology integration instruction as part of their teacher education as their younger counterparts. Four priorities that emerged for educational stakeholders to consider in order to help transition educators from technology operators to technology facilitators and integrators (Gorder, 2008) are: 1) planning for technology, 2) addressing teacher concerns, 3) understanding and addressing the technological ability differences amongst staff, and 4) comentorship and collaboration.
\end{abstract}

Keywords: Technology; Tenured Teachers; Professional Development; Technology Innovation

\section{INTRODUCTION}

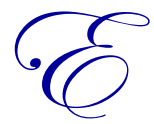

ducational stakeholders are being asked daily to improve their practices to better deliver educational services to the youth that they serve. Many educators are looking for improvements to educational resources and how they are implemented as a means to school improvement. Teachers and technology are widely considered as the two of the most impactful educational resources in schools today. Teachers are education's biggest resource and its biggest expense; they balance the needs of individual students and whole classrooms, parental and administrative whims, and personal and district ideologies. Technology, meanwhile, is at its very center an idea of change, a constantly moving matrix of hardware, software, and human interaction, and is expanding at a rate never before seen in education or history. The ever-changing relationship between teachers and the technology they integrate in their classroom has become a vital function of the education system.

Research in the field of technology integration has reported a wide variation of factors that influenced success, perceived or actual. Engaging in qualitative studies of teacher experiences in technology integration provide in-depth insights not currently available about transitioning teachers from technology operators to technology facilitators and integrators (Gorder, 2008). It is vitally import to expand research possibilities on technology integration in order to match its increasing importance to successful school improvement and student learning. Technology integration has become a phenomenon in the education system that must be researched in a deep, rich, profound way.

This article will present an overview of significant research that addresses technology integration, and then will consider technology integration issues with teachers based on their teaching experience and age. A detailed discussion will ensue concerning four prominent themes embedded within the research assignment and the articles reviewed, as the themes pertain to technology integration: 1) planning for technology, 2) addressing teacher concerns, 3) understanding and addressing technological ability differences amongst teachers, and 4) comentorship and collaboration. These themes will be illustrated using both the research reviewed and the research assignment findings. The final section will have recommendations for further research that would be beneficial to educators who are looking to increase the quantity and quality of the technology integration in their classrooms. 


\section{LITERATURE REVIEW}

Recent research is deepening the descriptive frameworks of how teachers are integrating technology in their classrooms. Harris and Hofer (2011) stated that each teacher had a "nexus of curriculum requirements, students' learning needs, available technology affordances and constraints, and...realities of school and classroom contexts"(p. 211) that must be accounted for when teachers plan for technology integration. Harris and Hofer believe that these can all be addressed through the idea of TPACK - technological pedagogical content knowledge (Thompson \& Mishra, 2007-2008). The focus of TPACK centered more on encouraging teachers to evolve their pedagogy and less on adding to their workload.

Research by Koehler, Mishra, and Yahya (2005) shed light on a collaborative technology integration initiative between university professors and technology graduate students. The researchers applied the theory of TPACK to their initiative and focused on the quantity, quality, and disbursement of discussion between professors and their graduate students as they collaborated on an online course design. Koehler, Mishra, and Yahya labelled this course development style as "learning technology by design" (p.744). There were clear parallels between the collegial dynamic and the technology-integration-development style in this research and the collegial dynamic and technology integration development within the school where I completed my research assignment.

Research by Zhao \& Cziko (2001) furthered the idea of teacher driven technology integration through the lens of the Perceptual Control Theory. Perceptual Control Theory asserts that humans strive to establish and control internal goals that they strive to meet over external goals (p. 9). Zhao \& Cziko found that technology integration was viewed as a low level goal for teachers, as compared to existing high level goals such as content instruction and standardized testing results. The time intensive nature of technology integration was also viewed as a possible disturbance to these higher level goals (p. 17). In short, technology integration may create more problems and fewer solutions for teachers in achieving the goals that they deem to be most important, and this is especially so for the longer tenured teachers who are more entrenched in their teaching routines and teaching styles.

Other research has looked at possible correlations between age based generational attitudes of teachers towards technology and their professional technology use. Pegler, Kollewyn and Crichton (2010) looked at the technology use of teachers of varying age groups in both their personal and professional capacities. They found that there was no difference between teachers of various age groups in the time spent in strictly professional technology use that had no social or out of school purpose. They also reported equal amounts of frustration, achievements, and success rates amongst all ages of teachers (p. 455). Pegler, Kollewyn and Crichton's research focused on delineating between professional and personal technological knowledge and attitudes as well as comentorship and collaboration between teachers of different technological, pedagogical, and content levels.

Liu and Szabo (2011) also addressed the attitudes of teachers towards technology integration and how it changed over a four year period. Liu and Szabo placed an emphasis on the reduction of teacher concerns towards technology integration as a key pillar to help offset the constant demands of implementing new technology integration based procedures. These procedures based around technology add to the "special burden on teachers who too often are concentrated on curriculum as related to standardized assessment"(p.20). These concerns were labelled according to the type of technology user the teacher was as well as the type of concern that the teacher had with technology as they contemplated integrating it into their classroom.

\section{RESEARCH ASSIGNMENT}

The research assignment studied the technology integration experiences of three teachers with more than ten years teaching experience. The main research question was: what are the technology integration experiences of three urban western Canadian school teachers with more than ten years teaching experience? The following subquestions were addressed:

- What have been the successes and challenges for teachers when integrating technology into their classrooms?

- What factors have contributed to the successes and challenges of teachers when integrating technology in the classroom? 
One on one interviews were digitally audio recorded then transcribed for analysis. Teachers also completed a one page questionnaire on their technology background and experiences. The findings of the research assignment suggested that teachers who were not exposed to technology as much or as early as their younger colleagues have still attempted to integrate technology to the best of their ability, with varying amounts of perceived success. All interviewed were united in the frustrations as well as the roadblocks they have experienced while integrating technology into their classrooms. Interestingly, they also all reported contentment with the amount of technology they currently used in their daily lessons.

Analysis of the data revealed the factors that influenced the participants' technology integration (TI) experiences. These factors included the perceived successes and challenges for teachers when integrating technology into the classroom, as well as the dynamics that have contributed to the TI successes and challenges. Analysis revealed two major themes: 1) personal experiences, which addressed personal modelling/early experiences as well as personal perceptions/feelings, and 2) professional experiences, which addressed external and internal influences.

\section{PERSONAL EXPERIENCES}

All three of the participants were able to communicate their personal connections to TI in throughout their interviews. Joey, Susan, and Michael also effectively articulated the impact of their personal experiences on their in class technology integration.

Modelling words and actions from parents, friends, and teachers is one of the most common strategies that people use to learn new skills and behaviors. None of the participants identified any early technology users to model their behavior after; however, both Joey and Susan mentioned their parents as factors in their formation of their views on TI or early experiences around technology. Susan stated that her dad was the primary source for her definition of TI:

He is one of the most learned people I know and he has never touched a computer but he can still talk of all sorts of social, political issues with just his mind. He has read so much and he continues to do so but he couldn't and doesn't want to use computer or technology. (Susan)

The participants varied in their early experiences with technology. Michael recognized the potential of using technology in his subject matter during University and had been offered a one year internship at a large local high school to explore the potential of TI before being offered a full time teaching position elsewhere. Joey shared his bad initial experience with technology in a remote rural school due to hardware issues and scarcity of available software. Susan's early experience had a similar sense of "failure" (Susan), but also of novelty as well.

The participants freely shared their personal feelings of frustration, stress, and wariness. These feelings were identified as a result of numerous factors, including:

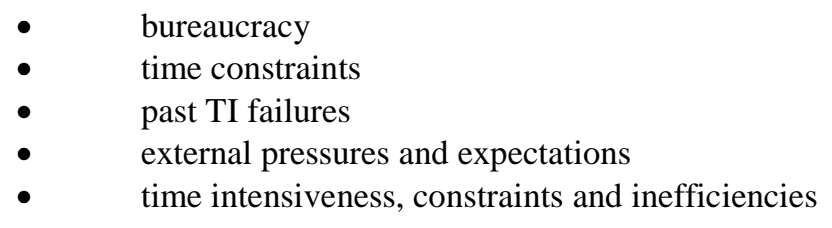

Susan stated that it "would be frustrating because sometimes it's - there is so much to go through that it takes so much time to find out what you've been looking for is absolutely horrendous". Michael stated that:

...it's a massive amount of work that I have to do and you couple that with the fact that I have to do teaching and record keeping and all the other tasks of the teacher, and sometimes it can be quite stressful. (Michael)

Joey described one instance of unsuccessful TI as so frustrating that it was "painful". By contrast to the consistent emphasis placed of stress or frustration, the participants at times struggled to provide any other emotions without further prompting. These prompted responses included "relief" (Susan) and "tiresome" (Joey) as well as stronger emotions associated to technology's potential, such as "wonderment... awestruck...exhilaration" (Michael). 
All participants shared their general perceptions of technology, its general impact in education, their lives and in their students' lives. Michael acknowledged that "education - it will be a reflection of society and ... its impact to society". Michael and Joey both noted that there is an increasingly strong connection between students and computers: "I think that computers have become an extension of them" (Joey). Susan admitted to her own dependence on technology and connected it to a diminishing of independence and interdependence as a society; "you hear about studies done which show people who are so reliant on the cell phone and stuff I mean and I am one of them now....I think sometimes the people are paralyzed without it and I don't want - I want people to be able to use basic tools" (Susan). Joey and Susan both communicated negative self perceptions about technology ability when asked, while Michael spoke of the increasing rate of technological advances and the ability to "cope" with them.

\section{PROFESSIONAL EXPERIENCES}

The participants were also able to communicate their professional experiences with TI throughout their interviews. Joey, Susan, and Michael effectively articulated the impact of both external and internal influences on their TI experiences.

External influences on TI were identified as government influence, school board influence, professional development opportunities, and available external resources. The participants varied only slightly in their experiences with government influence. Susan indicated that government initiatives and directives created a sense of forced compliance from the top down applied pressure to create TI innovations. Joey spoke of "bureaucracy" that comes with government influences triggered frustration. Michael varied a bit from the others in his views. Although he acknowledged the bureaucracy and top down nature of his experiences with TI, he also said that he benefitted from some of the government initiatives. Michael stated that the initiatives also inspired a focus on areas of need for his classroom and resulted in increased success with those issues. The respondents collectively found that government influences to their technology integration experiences were frustrating.

There was a strong consensus in the praise and positive experiences the respondents had with the way the local school board approached their TI policy. Michael, Susan, and Joey all agreed that funding and support for TI was above and beyond what they believed was the norm with other school boards: "most of it has been kind of left to our task, I guess. Kind of practicing backwards planning... the sky is the limit...it is up to us" (Joey). This board support also extends out into teacher professional development:

I really appreciate the fact that (the school board) has really made it -- emphasized over the years that professional training and development was important and they have gone out of their way to support it because without that, I wouldn't be where I am today. (Michael)

Interestingly, the board support in both professional development and resource purchasing has not equated to consistent success. Michael estimates that $60 \%$ of his PD budget over the year had been spent on unique TI courses, which reflects both the constant need for TI development as well as the relatively short time in which technologies are current. However, all three interviewees also spoke of their experiences with PD or consultant based workshops that did not address the wide variation of technology IQ amongst the staff. The PD content also often did not fall within the contexts of their subjects or their students. The participants recommended that future TI PD endeavours to be "specialized" (Michael), "constructivist" in nature (Joey) and "collaborative" (Susan).

Experiences with resources were also identified as a frustration and barrier. Michael spoke of the fact that there were so many different software resources to choose from and that "the software programs (are) updated over time, so to be able to cope with all the updates... it makes it difficult -- very difficult". Susan's experience was that there was little or no integration of government curriculum and TI resources. Susan asserted that "If there is no resource out there about how are we supposed to do it? And if there is no resource, then (we) make it up". Michael shared how this is compounded by upcoming curriculum changes:

The curriculum in math is completely changing, so I happened to adapt all my curriculum in a way that supports me as far as pushing towards technology because I want to design my courses, so that's integrated in them, but on the other hand, it's massive amount of work. (Michael) 
The participants shared internally developed TI experiences such as school based TI development, classroom TI development, and student interactions. The interviewees stated that their experiences had taught them that internal development of TI should be rooted in effective assessment, self determination for staff, peer collaboration and support within a contextual framework. Joey shared that "what I found most helpful for somebody to actually sit down with you and get a glimpse of how you work as a teacher and from there... help you decide what you need to learn" (Joey). Michael also mentioned collaboration and communication in school development of TI, but also pointed out that "it appears that we're going to have to go to more and more specialized function".

Classroom development was identified as where the majority of the educators' integration experiences lied. The range of the participants' TI was extremely wide, and included:

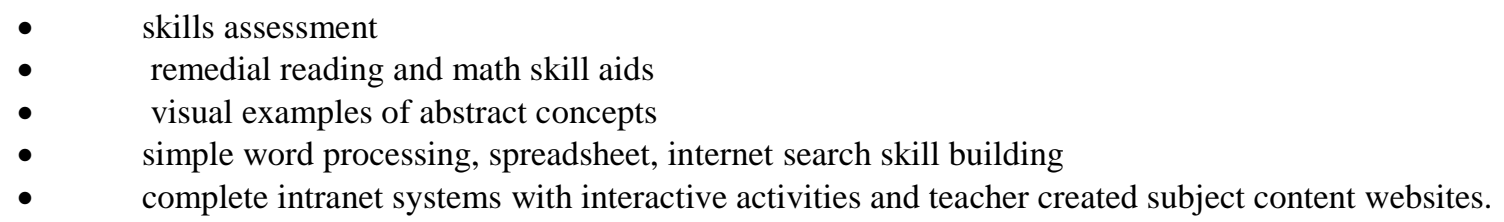

All three participants identified that they have achieved TI in their classrooms to their satisfaction by combining these uses.

The participants emphasized that the significance that they attached to technology integration was a bigger factor than the actual uses of technology to successful implementation. The teachers spoke of how TI success came when they realized that it was component of a more holistic educational experience for their students that empowered them to learn. All three participants stated that in their experience TI only worked for them when it was student centered, student directed, interactive, and in the students' context. Technology was seen not as a goal, but a tool; "it's only as useful as the teacher is able to bridge the gap between the student and knowledge" (Michael). Joey's experience in the classroom taught him that "the less work that I put in and the more wide open that you give the assignment and just let the students create or express themselves on a computer, the better". Susan, Joey, and Michael agreed that balance was a key component in creating an effective classroom TI framework.

The teacher-student technology interactions often involved behavior management, appropriate use of the technology, as well as student interest and engagement with the TI based tasks. All three participants commented how Web 2.0 social media advances had created a new set of challenges. Joey recalled how Facebook had become such an integral part of students' social lives that "it's their lifeline and you are telling them to shut it down". Susan stated that these sites and computer based games were escapes from the work she gave and that "nobody can force you to do the work". Michael noted that like teachers, students have a wide variation in technology IQ's that affects their TI engagement:

Some of my students have no desire whatsoever to get onto the computer and get integrated into the technology ...so we have to balance that out with learning basic skills that are necessary for them to survive in the world in which they live (Michael).

\section{THEMES FOR DISCUSSION}

Four major themes emerged from the review of the literature and the research assignment. For teachers to integrate technology in a way that positively impacts their classroom environment, researchers and policy makers should prioritize 1) planning for technology, 2) addressing teacher concerns, 3) understanding and addressing the technological ability differences amongst staff, and 4) comentorship and collaboration.

\section{PLANNING FOR TECHNOLOGY}

Planning for technology integration can be an arduous and unique task. The dynamic nature of technology requires constant attention and development, and often the technology becomes available before there is a comprehensive plan in place to use it. Koehler, Mishra, \& Yahya's (2007) research looked at the complicated web of 
functions that technology integration planning involved. They coded technology integration functions in ten different areas, but focused on content, pedagogy, technology, content pedagogy, content technology, pedagogy technology, and content pedagogy technology (p.749). Rather than planning each function individually, the researchers viewed the interconnected relationships between content, pedagogy, and technology in their study. The overarching goal of achieving thorough technology integration happened when planners considered the "transactional and co-dependent construction that indicated a sensitivity to the nuances of technology integration" (p.758).

Harris \& Hofer (2011) also looked at instructional planning in a professional development initiative using a TPACK structure. The type of planning studied by Harris \& Hofer was distinctive from traditional methods of professional development or technology integration planning. Technology integration was not the reason for the planning, but rather an overall instructional plan that took into account technological, content, contextual, and pedagogical considerations. Although curriculum and content were still given first priority before and after their professional development initiative, teachers allowed more strategic consideration to technological influences that could impact student learning after their professional development (p.225). The planning described by Harris \& Hofer also satisfied Zhao \& Cziko's (2001) three conditions to ensure that teachers use technology more in their classroom: that is 1) teacher belief that technology facilitated a higher level goal better than strategy previous to the technology 2) teacher belief that using technology will not disturb other high-level goals, and 3) belief that the teacher had the ability and resources to use technology (p.21).

The research assignment revealed a disconnect between the technology planning, curriculum planning, and the pedagogy of the teachers interviewed. Susan saw little coordination between government-produced curriculum and technology resources. She found no technology resources to support the recent overhaul to her course curriculum "If there is no resource out there how are we supposed to do it?" (Susan). The teachers interviewed also noted that the professional development and consultant based workshops they had experienced at their school were not relevant to their curriculum or teaching style. All three teachers agreed that effective planning that includes a technology plan within their pedagogical structures was a key component to a more technologically integrated classroom.

\section{ADDRESSING TEACHER CONCERNS}

Research by Liu \& Szabo (2009) investigated teachers' concerns with technology integration over a four year period. Using Hall et al's SoC Questionnaire (1977), the researchers identified seven types of teacher concern with technology integration - awareness, informational, personal, management, consequences, collaboration, and refocusing (p.10) - that varied with teacher technology experience level. The highest levels of teacher concern reported in the research focused on wanting more information on technology, how technology would affect the teacher, and the implementation of new ideas integrating technology that may work better than old ideas. Identifying and addressing teacher concerns and perceptions of technology integration could help empower teachers to further engage with technology in their classrooms.

Analysis of research by Zhao \& Cziko (2001) lends insight into the importance of teacher motivation and concern with technology integration. Their research explained teachers' approaches to technology integration through the lens of the Perceptual Control Theory. This theory stated that teachers strived to meet the internal goals they had set for themselves based on their own criteria. Greater attention was given to higher level goals, and lower level goals were dismissed or delayed if they disturbed the higher level goal achievement. Zhao \& Cziko reported that "using technology may create more disturbances for many teachers than not using technology"(p.18). This may be especially true for more tenured teachers, such as the teachers interviewed for the research assignment, who had more established instructional routines. Frustration resulted when teachers saw how technology could be a means to achieving the higher level internal goals they may have, but could also possibly disrupt higher level goal achievement. Zhao \& Cziko maintain that teachers need to believe that technology integration is within their ability range and will increase high-level goal attainment, while decreasing disturbances to those goals, before making a thorough commitment (p. 21). The participants in the research assignment described their concerns and perceptions at length. Their concerns focused around the bureaucracy, past technology integration failures, and external pressures from stakeholders, and they also mentioned the time intensive nature of technology integration. 


\section{Understanding \& Addressing Technological Ability Differences Amongst Teachers}

There are undeniable differences in teachers' technology experience that impact the teachers' receptiveness and ability to integrate technological aspects into their lesson delivery. This is unique to technology and more experienced teachers, most of whom did not experience technology integration in their primary or university education. Liu and Szabo (2009) described the three types of technology users as inexperienced, experienced, and renewing (p.15). These varying levels of technology users correlated with varying intensities of concern about the different stages of technology use. This intensity in approach to technology integration was compounded because "technology resources and methods of integrating technology across the curriculum change much faster than teachers can keep up with" (pp.19-20).

It is important to delineate between social/entertainment uses and professional/pedagogical uses of technology in the classroom. Technology use that is favored by younger generations and focused on entertainment and socializing, although potentially skill building, did not necessarily correlate to increased technology integration in the classroom. Pegler, Kollewyn and Crichton (2010) noted that although younger generations within their research used technology much more frequently outside of school than their older colleagues, that they were often unable to integrate technology into their instruction (p.454). Although there is a possibility of scaffolding teacher and student learning from social/entertainment based use to educational/professional use, it is not guaranteed. Within the research assignment, Susan was an example of the juxtaposition of personal and professional technology experiences possible within a school's staff. Susan admitted in her interview that she had become reliant on her own personal technology away from the school, but in a work context she advocated that students be able to use "basic tools" rather than technology.

\section{Comentorship and Collaboration}

Pegler, Kollewyn and Crichton (2011) used the term comentorship to describe a professional development structure that combined the strengths of various generations of teachers. The idea expressed was that older teachers with more experience had a content knowledge and pedagogical comfort level that younger, less experienced teachers did not have. Conversely, younger teachers had a comfort level with technology that older teachers did not have. Pegler, Kollewyn and Crichton maintain that professional development should support a collaborative skill sharing between these two groups of teachers that leaves each group more skilled and comfortable in all areas of instruction. This would also bolster the TPACK theory of instructional development mentioned earlier in this paper and also mentioned in the discussion area of Pegler, Kollewyn and Crichton's article.

This type of comentorship was featured in the research done by Koehler, Mishra, and Yahya (2007). The online course development featured in the research was anchored by the merging of ideas between the content-andpedagogy-focused faculty members and the technology-focused master's students. The research revolved around the communicative factors that influenced these collaborations; the types of discussions that occurred, who initiated them, and the evolution of the discussions over time. As a result of this comentorship all involved "showed tremendous growth in their sensitivity to complex interactions between content, pedagogy, and technology" (p.759).

Some of the most positive technology integration experiences reported in the research assignment revolved around the collaboration between teachers. Susan recommended that any future professional development workshops be collaborative and Michael mentioned that collaboration and communication would be keys to deepening technology integration on a school wide level. Joey stated that "What I found most helpful (is) for somebody to actually sit down with you and get a glimpse of how you work as a teacher and from there ...help you decide what you need to learn" (Joey). Comentorship, collaboration, self-determination, and peer support were factors that teachers in my research assignment identified as necessary to increasing technology integration in their school.

\section{Considerations for Future Research}

Although the articles and the research assignment that I have presented have provided themes and considerations for improving technology integration, this in-depth analysis has also indicated considerations for 
future exploration. Research that is more longitudinal and contextual in nature will help educators locate, identify, and develop a technology integration protocol that works best for them.

Koehler, Mishra, and Yahya (2007) alluded to the fact that developing technology integration in a school "is a multigenerational process, involving the development of deeper understandings of the complex web of relationships between content, pedagogy and technology" (p.758). Liu and Szabo (2009) also concluded that "the process of integrating technology into the curriculum seems longs and requires tremendous amount of time and energy" (p.18). This type of longitudinal view of technology integration should be reflected in the design of research in order to better gain understanding of all of technology integration's moving parts.

The research assignment described in this article was a snapshot of experiences gathered from over thirtyfive years' worth of teachers' efforts to integrate technology into their classroom. Although informative, their viewpoints and experiences were just a snapshot taken at the time and place of their interviews, and possibly influenced by the fleetingness of the previous few hours of work. Although impossible for the purposes of this study, the teachers' expertise would have been better served and revealed if they were studied over a four year time period, as was done by Liu \& Szabo (2009). Engaging in longitudinal studies will allow educators to gain better insight into the dynamic, ever changing nature of technology and its place in the classroom.

Technology integration is also dependent on many contextual factors, including local curriculum requirements, students' learning needs, technology based funding, as well as school and classroom contexts (Harris $\&$ Hofer (2011). These variables are numerous and range widely from country to country, area to area, and school board to school board. Thompson \& Mishra (2007-2008) acknowledged this point when they expanded on the TPACK theory by adding contextual knowledge. Many of these contextual factors are as particular as they are impactful and it is important that each local school and/or school board address their own particular contexts to maximize their technology integration potential. The site of my research assignment was an urban school that works with at risk adolescents who struggle with barriers such as homelessness, poverty, mental illness, and addiction. These contextual variables significantly impacted both the teachers' experiences with technology integration with their students as well as their responses to my assignment questions. It would be in a school district's best interest to ensure that they engage in research that is relevant and particular to their own unique situations and challenges.

\section{CONCLUSION}

Improvement is not simply trying something different over and over until a result changes, but a longitudinal, intentional action plan. Stoll (2009) stated that improvement "is a process; a journey with many subtleties that even the richest of case studies can't capture" (p.116). In my teaching experience technology is most often associated with innovation in the classroom. Innovation stems from educational stakeholders establishing a culture of learning in their school. However, innovation through technology on its own is not improvement unless it is implemented in a balanced, sustainable, and student focused way. Wheatley (2000) believed that "meaningful change is at least a three to five year process" (p.345). Innovation best occurs organically when educators are engaged in a culture of learning and given opportunities within a distributed leadership paradigm to address studentlearning issues.

Referring back to my research assignment, the participants noted that their success in implementing technology integration was only achieved in their own minds when they made the innovation a part of a more holistic educational experience that empowered the students to learn. Technology use was not the goal, but a means to achieve a greater goal. Educators that encourage a balance between innovation, sustainability, and effectiveness, thereby promoting both creativity and prudence, will engage more stakeholders into a transformational school environment.

\section{AUTHOR INFORMATION}

Jerad Cox has been an English and Audio Production teacher for the past eleven years at the Boyle Street Education Centre (http://www.bsec.ab.ca) in Edmonton, Alberta, Canada. Jerad works with disadvantaged at risk youth in Edmonton's inner city in hopes of reengaging them back into the educational process. He recently obtained his 
Masters of Education in Educational Studies from the University of Alberta. A self-described 'change agent', Jerad enjoys the daily challenge of pursuing personal, professional, academic, and spiritual improvement. Most importantly, Jerad is a happily married father of 3. Jerad Cox, Boyle Street Education Centre, Edmonton, Alberta, Canada. E-mail: jcox@bsec.ab.ca

\section{REFERENCES}

1. Fullan, M. Leading professional learning. School Administrator, 63(10), 10. Retrieved from http://login.ezproxy.library.ualberta.ca/login?url=http://ovidsp.ovid.com.login.ezproxy.library.ualberta.ca/o vidweb.cgi?T=JS\&CSC=Y\&NEWS=N\&PAGE=fulltext\&D=eric3\&AN=EJ757397

2. Fullan, M. (2002). The change leader. Educational Leadership, 59(8), 16-20. Retrieved from http://login.ezproxy.library.ualberta.ca/login?url=http://ovidsp.ovid.com.login.ezproxy.library.ualberta.ca/o vidweb.cgi?T=JS\&CSC=Y\&NEWS=N\&PAGE=fulltext\&D=eric3\&AN=EJ644975

3. Gorder, L. M. (2008). A study of teacher perceptions of instructional technology integration in the classroom. Delta Pi Epsilon Journal, 50(2), 63-76. Retrieved from http://login.ezproxy.library.ualberta.ca/login?url=http://ovidsp.ovid.com/ovidweb.cgi?T=JS\&CSC=Y\&NE WS=N\&PAGE=fulltext\&D=eric3\&AN=EJ826493

4. Hall, G.E., George, A.A., \& Rutherford, W.L. (1977). Measuring stages of concern about the innovation; A manual for use of the SoC questionnaire. Austin, TX: Southwest Educational Development Laboratory. Retrieved from http://login.ezproxy.library.ualberta.ca/login?url=http://ovidsp.ovid.com.login.ezproxy.library.ualberta.ca/o vidweb.cgi?T=JS\&CSC=Y\&NEWS=N\&PAGE=fulltext\&D=eric1\&AN=ED147342

5. Harris, J. B., \& Hofer, M. J. (2011). Technological pedagogical content knowledge (TPACK) in action: A descriptive study of secondary teachers' curriculum-based, technology-related instructional planning. Journal of Research on Technology in Education, 43(3), 211-229. Retrieved from http://login.ezproxy.library.ualberta.ca/login?url=http://ovidsp.ovid.com.login.ezproxy.library.ualberta.ca/o vidweb.cgi?T=JS\&CSC=Y\&NEWS=N\&PAGE=fulltext\&D=eric3\&AN=EJ918905

6. $\quad$ Koehler, M. J., Mishra, P., \& Yahya, K. (2007). Tracing the development of teacher knowledge in a design seminar: Integrating content, pedagogy and technology. Computers and Education, 49(3), 740-762.

Retrieved from http://login.ezproxy.library.ualberta.ca/login?url=http://ovidsp.ovid.com.login.ezproxy.library.ualberta.ca/o vidweb.cgi?T=JS\&CSC=Y\&NEWS=N\&PAGE=fulltext\&D=eric3\&AN=EJ765104

7. Liu, Y., \& Szabo, Z. (2009). Teachers' attitudes toward technology integration in schools: A four-year study. Teachers and Teaching: Theory and Practice, 15(1), 5-23. Retrieved from http://login.ezproxy.library.ualberta.ca/login?url=http://ovidsp.ovid.com.login.ezproxy.library.ualberta.ca/o vidweb.cgi?T=JS\&CSC=Y\&NEWS=N\&PAGE=fulltext\&D=eric3\&AN=EJ828157

8. $\quad$ Pegler, K., Kollewyn, J., \& Crichton, S. (2010). Generational attitudes and teacher ICT use. Journal of Technology and Teacher Education, 18(3), 443. Retrieved from http://login.ezproxy.library.ualberta.ca/login?url=http://proquest.umi.com.login.ezproxy.library.ualberta.ca/ pqdweb?did=2270975131\&Fmt=7\&clientId=12301\&RQT =309\&VName=PQD

9. Stoll, L. (2009). Capacity building for school improvement or creating capacity for learning? A changing landscape. Journal of Educational Change, 10(2-3), 115-127. doi: 10.1007/s10833-009-9104-3

10. Thompson, A.D., \& Mishra, P. (2007-2008), Breaking news: TPCK becomes TPACK! Journal of Computing in Teacher Education, 24(2), 38, 64.

11. Wheatley, M. (2000). Goodbye, command and control. The Jossey-Bass reader on educational leadership. (pp.339-347). San Francisco: Jossey-Bass.

12. Zhao, Y., \& Cziko, G. A. (2001). Teacher adoption of technology: A perceptual control theory perspective. Journal of Technology and Teacher Education, 9(1), 5-30. Retrieved from: http://login.ezproxy.library.ualberta.ca/login?url=http://ovidsp.ovid.com.login.ezproxy.library.ualberta.ca/o vidweb.cgi? T=JS\&CSC $=$ Y \&NEWS=N\&PAGE=fulltext $\& D=$ =ric $3 \& A N=E J 637528$ 
NOTES 